\title{
Comment on Baltic provenance of top-Famennian siliciclastic material of the northern Rhenish Massif, Rhenohercynian zone of the Variscan orogen, by Koltonik et al., International Journal of Earth Sciences (2018) 107:2645-2669
}

\author{
M. Francisco Pereira ${ }^{1} \cdot$ J. Brandão Silva² Cristina Gama $^{1}$ \\ Received: 5 December 2018 / Accepted: 21 February 2019 \\ () Geologische Vereinigung e.V. (GV) 2019
}

\begin{abstract}
Koltonik et al. (Int J Earth Sci 107:2645-2669, 2018) evidence that the Late Devonian siliciclastic rocks from the RhenoHercynian Zone, in Germany, derived from Baltica and Scandinavian Caledonides. This finding together with what is known about the provenance of the Pulo do Lobo and South Portuguese zones, in Portugal and Spain, reinforces the probability that Late Devonian basins may have been sourced from distinct terranes placed along the Variscan suture. Our comment intends to underline changes in the provenance of the Late Devonian basins along the active margin of Laurussia, and also, to improve the correlation model for the Variscan tectonic units from SW Iberia and Germany.
\end{abstract}

Keywords Detrital zircon $\cdot \mathrm{U}-\mathrm{Pb}$ geochronology $\cdot$ Provenance $\cdot$ Rheno-Hercynian Zone $\cdot$ Variscan belt

Koltonik et al. (2018) is a valuable contribution for understanding the provenance of the Late Devonian siliciclastic rocks from the Rheno-Hercynian zone. Their interpretation of the detritus having been derived from Baltica and Scandinavian Caledonides sources is quite remarkable. This result reinforces the probability that the Rheno-Hercynian basin may have been sourced from distinct terranes placed along the Variscan suture. We want to emphasize that Koltonik et al. (2018) did not explore this crucial point of view and thus failed a good opportunity to discuss the architecture and tectonic evolution of the Appalachian-Variscan belt. Despite this, Koltonik et al. (2018) includes a map of the Variscan belt presenting a correlation between SW Iberia and Germany, which we disagree with. From the above, our comment intends to: (1) underline changes in the provenance of

M. Francisco Pereira

mpereira@uevora.pt

J. Brandão Silva

jbsilva@fc.ul.pt

1 Instituto de Ciências da Terra, Departamento de Geociências, Escola de Ciências e Tecnologia, Universidade de Évora, Évora, Portugal

2 Instituto D. Luiz, Departamento de Geologia, Faculdade de Ciências da Universidade de Lisboa, Lisbon, Portugal the Late Devonian basins along the active margin of Laurussia (Rheno-Hercynian Zone, in Germany, and Pulo do Lobo and South Portuguese zones, in Portugal and Spain), and (2) discuss the correlation model for the Variscan tectonic units from SW Iberia and Germany.

The first obstacle to correlation is the inexistence of preDevonian rocks in the South Portuguese and Pulo do Lobo zones (SW Iberia), contrary to what happens for the RhenoHercynian Zone (Germany). The oldest Devonian rocks which have been dated in the South Portuguese Zone are volcanic rocks of the Pyrite Belt (Cercal porphyries with an age of c. $374 \mathrm{Ma}$; Rosa et al. 2009) which are overlain by siliciclastic rocks and minor carbonate rocks of the Upper Devonian São Luis Formation (Oliveira 1984) (Fig. 1). Siliciclastic sedimentation extends to the Upper DevonianLower Carboniferous siliciclastic rocks of the PhylliteQuartzite Formation (Pérez-Cáceres et al. 2017), which are conformably overlain by the c. 359-349 Ma volcanic rocks of the Volcanic-Sedimentary Complex of the Pyrite Belt (Rosa et al. 2009) (Fig. 2). In Spain, the Phyllite-Quartzite Formation unconformably overlies siliciclastic rocks of the Ronquillo formation, which have a maximum depositional age of c. $400 \mathrm{Ma}$ (Pérez-Cáceres et al. 2017) (Figs. 1, 2). The Volcanic-Sedimentary Complex of the Pyrite Belt is overlain by the Mértola and Mira formations, representing 